\title{
The political dynamics of portfolio design in European democracies
}

\author{
Ulrich Sieberer, University of Bamberg \\ Thomas M. Meyer, University of Vienna \\ Hanna Bäck, Lund University \\ Andrea Ceron, University of Milan \\ Albert Falcó-Gimeno, University of Barcelona \\ Isabelle Guinaudeau, Sciences Po Bordeaux \\ Martin Ejnar Hansen, Brunel University London \\ Kristoffer Kolltveit, University of Oslo \\ Tom Louwerse, Leiden Univers ity \\ Wolfgang C. Müller, University of Vienna \\ Thomas Persson, Uppsala University
}

Pre-print version of the accepted manuscript:

Sieberer, Ulrich, Thomas M. Meyer, Hanna Bäck, Andrea Ceron, Albert FalcóGimeno, Isabelle Guinaudeau, Martin Ejnar Hansen, Kristoffer Kolltveit, Tom Louwerse, Wolfgang C. Müller, and Thomas Persson (forthcoming). 'The political dynamics of portfolio design in European democracies', British Journal of Political Science.

\begin{abstract}
:
The design of government portfolios, i.e. the distribution of competencies among government ministries and office holders, constitutes a largely ignored aspect of executive and coalition politics. In this article, we argue that portfolio design is a substantively and theoretically relevant phenomenon with major implications for the study of institutional design and coalition politics. Based on comparative data on portfolio design reforms in nine Western European countries since the 1970s, we show how the design of government portfolios changes over time. Specifically, we show that portfolio design is changed frequently (on average about once a year) and that these reforms are more likely after changes in the prime ministership and the party composition of the government. Our findings suggest a political logic behind these reforms based on the preferences and power of political parties and politicians. They have major implications for the study of institutional design and coalition politics.
\end{abstract}




\section{Acknowledgements:}

We gratefully acknowledge financial support by the Austrian Research Association (ÖFG) and the Austrian Science Fund (FWF) under grant P25490. A previous version of the manuscript was presented at the 2017 ECPR General Conference in Oslo. We thank all participants for helpful feedback and suggestions. We also thank the anonymous reviewers of the British Journal of Political Science, and Teresa Haudum for excellent research assistance. 


\section{Introduction}

The formation of a new cabinet involves many decisions: Which parties form the cabinet? Which parties and individuals get to control which ministry? And what policy program does the cabinet agree upon? While these questions have been at the centre of scholarly attention for decades (for reviews see e.g. Laver 1998; Laver and Schofield 1990; Müller 2009), another crucial decision has been largely overlooked by political science research: How are government ministries designed, i.e. which ministries and office holders are in charge of what policy areas? While coalition researchers usually treat ministries as exogenous payoffs to be distributed, this article casts serious doubt on this assumption by showing that the makeup of ministries is often reformed in the context of coalition formation.

A few examples illustrate that the design of government portfolios is sometimes changed drastically. In 2016, the incoming British Prime Minister Theresa May created a new Department for Exiting the European Union charged with managing the Brexit process. In 2010, the Hungarian Prime Minister Victor Orbán reduced the number of ministries from fourteen to eight creating some ministries with extensive jurisdictions, e.g. a Department of Finance and Economics. Below the level of such comprehensive reforms involving the creation and termination of entire ministries, individual competencies are frequently shifted between existing ministries. For example, the jurisdictions for energy, consumer protection, urban development, and digital infrastructure were reassigned to new ministries at the beginning of the third German cabinet headed by Angela Merkel in 2013.

This manuscript introduces a comparative research project that systematically studies such reforms of portfolio design across nine Western European democracies. We define portfolio design as the distribution of competencies among government 
ministries and office holders (i.e. ministers and junior ministers). The manuscript argues that such reforms are substantively relevant phenomena that should affect policy-making and policy outputs and are theoretically important for various strands of political science research, most importantly the literatures on deliberate institutional design and coalition research. We discuss the scarce existing literature and argue that a systematic study of portfolio design should take a comparative approach without neglecting in-depth expertise of individual countries.

Towards this end, we introduce a new comparative dataset covering portfolio design changes in nine Western European democracies since 1970. Based on these data, the article investigates two fundamental research questions: first, how frequent are changes in portfolio design and thus how realistic is the assumption of ministries as exogenous payoffs that is central for the literature on portfolio allocation (e.g. Bäck et al. 2011; Laver and Shepsle 1996, 49)? Second, can political events related to changes in the government explain the timing of portfolio design reforms, which would suggest that such reforms are an integral part of the government formation process? Our empirical analysis first demonstrates that reforms occur frequently, on average roughly once a year. Furthermore, changes in portfolio design are much more likely after changes in the party composition of the cabinet and the person of the prime minister, whereas changes in the cabinet' ideological position and in the relative size of cabinet parties yield only weak additional effects. These findings suggest that portfolio design is indeed driven by a political logic and can be considered a distinct strategy that government parties employ to adapt the distribution of competencies to their advantage. We point to several implications of these findings for the general literature on institutional design and for coalition research in the concluding section.

\section{Why study portfolio design?}


Thus far, the design of cabinet portfolios has received little scholarly attention. This omission is surprising given the central role that ministries play in modern democracies. In this section, we outline three reasons for studying the politics of portfolio design: (1) the substantive importance of ministries in policy-making, (2) the theoretical relevance of deliberate institutional reform as a strategy of political actors, and (3) the theoretical and methodological relevance of the changes in portfolio design for the study of coalition politics.

First, portfolio design should affect government policy because ministries play a dominant role in the policy-making process. Ministries enjoy ample leeway in the drafting stage of new legislation and its subsequent implementation (e.g. Andeweg 2000; Huber and Shipan 2002; Knill and Tosun 2012; Laver and Shepsle 1994; Peters 2010; Schnapp 2004). Even though individual ministries are constrained (to varying degrees) by collective decision-making in the cabinet and central coordination by the prime minister (Dahlström et al. 2011; Peters et al. 2000; Rhodes and Dunleavy 1995), there is little doubt that ministries are crucial for everyday decisions and also enjoy disproportionate influence on major policy decisions within their jurisdiction (Laver and Shepsle 1994; Müller 1994). Accordingly, changes in the design of portfolios, especially the reallocation of jurisdictions from one ministry to another, should affect policy-making.

This effect is independent of what position one takes on the much-disputed question of how strong the political leadership, i.e. the minister, is able to steer policy within her department. If minsters are strong, they can put their own stamp on policy decisions so that changes in portfolio design should affect policymaking due to the impact of individual ministers, especially if jurisdictions are shifted between ministries controlled by different parties. If, on the other hand, policymaking is dominated by the 
ministerial bureaucracy, differences in the preferences of bureaucrats, established links to policy networks and interest groups, as well as ministry-specific ways of framing problems and possible solutions should lead bureaucrats in different ministries to perceive and address policy problems differently (e.g. Sabatier and Weible 2007; Scharpf 1997, 39-40; Smeddinck and Tils 2002, 262-66). This effect should be particularly visible if policy decisions have to balance conflicting goals. For example, energy policy involves a fundamental trade-off between economic prerogatives and environmental concerns. It is plausible to expect that this trade-off will be addressed differently depending on whether energy policy is drafted in a ministry of economics or a ministry of the environment.

Beyond the expected policy impact, changes in portfolio design are often symbolic political events that are used to signal specific issue emphasis of the government (Derlien 1996; Mortensen and Green-Pedersen 2015). Examples include the creation of super-ministries such as the Ministry for Economics and Labour in Germany in 2002, the creation of the Department for Exiting the European Union ('Ministry for Brexit') in Britain in 2016, and the establishment of environmental ministries in many countries in the 1980s. Both the influence of ministries on policymaking and the political signalling effect make reforms of portfolio design substantively relevant phenomena.

Second, reforms of portfolio design constitute a distinct, but thus far largely ignored strategy that political actors can use in pursuit of their substantive interests. Rational choice institutionalist research, in particular, claims that actors reform institutional rules if they expect a different institutional setup to be more suitable for reaching their substantive goals (e.g. Diermeier and Krehbiel 2003; Ostrom 2005; Tsebelis 1990, Ch. 4). Empirical research found support for this claim in the design of electoral system 
(e.g. Benoit 2004, 2007; Gallagher and Mitchell 2005; Renwick 2011; Vowles 1995), parliamentary organization (e.g. André et al. 2016; Binder 1996; Dion 1997; Schickler 2000; Sieberer and Müller 2015; Zubek 2015), and political regime types (Cheibub 2007; Przeworski 1992). Surprisingly, however, there is very little empirical research on the internal organization of the executive branch that tests whether these theoretical arguments are also valid for the distribution of competencies between ministries. Given the substantive importance of ministries, this question is essential for a general understanding of institutional reform as a deliberate strategy of political actors in parliamentary democracies.

Third, portfolio design is directly relevant for the study of coalition politics because it challenges the standard assumption that ministries are exogenous payoffs to be distributed in coalition formation and because it points to an additional mechanism for mutual control within the cabinet. Coalition research treats ministerial positions as key payoffs in the coalition formation game, either for the office benefits they entail or for the influence they provide on policy (Druckman and Warwick 2005; Laver and Schofield 1990; Raabe and Linhart 2014). Thus, an established strand of research analyses the allocation of ministries between coalition partners, both with regard to the quantitative allocation and to the question of which specific ministries are assigned to which party (e.g. Bäck et al. 2011; Carroll and Cox 2007; Ecker et al. 2015; FalcóGimeno and Indridason 2013; Laver 1998; Laver and Schofield 1990; Raabe and Linhart 2015; Verzichelli 2008; Warwick and Druckman 2006).

This research usually assumes (often implicitly) that portfolios are fixed and that their design is exogenous to the allocation process. One justification for this assumption is the need to hold some aspects constant in order to increase the traceability of the assignment process, especially for modelling purposes (Laver and Shepsle 1996, 49- 
50). While this argument is methodologically valid, it can be problematic if political actors frequently and deliberately alter the makeup of ministries in the allocation process. This would suggest that the design of government portfolios is an essential element of the government formation process that deserves explanation. Previously available data and the new empirical evidence we present below indicate that this may well be the case.

Moving beyond the allocation process, the design of cabinet portfolios can also contribute to the literature on coalition governance (e.g. Carroll and Cox 2012; Martin and Vanberg 2011; Strøm et al. 2008; Thies 2001). For one, the allocation of related jurisdictions to different ministries controlled by different parties can be conceptualized as an additional mechanism by which coalition partners control each other and reign in ministers from other parties (Saalfeld and Schamburek 2014). Furthermore, portfolio design can be used to strengthen the position of the prime minister by creating parallel structures in the prime minister's office to oversee policymaking within ministries (Fleischer 2011) or by allocating jurisdictions to specific ministers in order to reduce preference heterogeneity and thus the danger of agency loss (Dewan and Hortala-Vallve 2011). Third, portfolio design also matters for the analysis of individual ministerial careers because removing or granting competencies can be a mechanism for prime ministers and other government leaders (e.g. leaders of smaller coalition partners) to punish or reward individual ministers (Indridason and Kam 2008).

\section{Conceptualizing and measuring portfolio design}

Despite its substantive and theoretical importance, the politics of portfolio design is largely uncharted territory. Existing research mainly focused on the number of ministries as a rough indicator of portfolio design, both in comparative analyses (Davis 
et al. 1999; Indridason and Bowler 2014; Verzichelli 2008) and in single country studies (for Denmark: Mortensen and Green-Pedersen 2015; for Germany: Derlien 1996; Lehnguth and Vogelgesang 1988; Saalfeld and Schamburek 2014; for the UK: Heppell 2011; Kavanagh and Richards 2001; Pollitt 1984; White and Dunleavy 2010). These studies show that cabinet size varies massively both between countries and over time. A brief look at a sample of 29 European democracies since 1945 (or the date of democratization) shows that in an average country, the number of ministers in the largest cabinet was almost 80 percent higher than in the smallest one. In 19 of 29 countries, the difference was at least 50 percent, in seven even 100 percent or more. These differences stem from frequent changes in cabinet size: Only 37 percent of all cabinets in this sample contain the same number of ministers as the previous one whereas 28 (34) percent witness a decrease (increase) in cabinet size. ${ }^{1}$

However, changes in cabinet size are only the tip of the iceberg and mask frequent shifts in jurisdictions between established ministries. Such changes have so far only been documented in a limited number of single-country studies. A study of Britain states that 125 government departments were involved in reconfigurations from 1950 to 2009, while the net change in the number of ministries was much smaller (White and Dunleavy 2010, Figure 6). In Germany, 38 reforms of portfolio design between 1957 and 2015 affected 147 ministries. Of those changes, only a small minority involved the creation (6) or termination (13) of a ministry whereas 128 were jurisdictional shifts between established ministries (Sieberer 2015).

Such single-country studies have obvious merits for understanding the country analysed and can dig much deeper with regard to data collection and context specific

\footnotetext{
${ }^{1}$ Own calculations based on data from the European Representative Democracy Data Archive (Andersson et al. 2014).
} 
explanations. However, they are inherently limited with regard to generalizability and compatibility with existing comparative work (especially in the area of coalition research). Furthermore, single country studies cannot assess the impact of institutional factors that are stable within countries such as second-order rules on how portfolio design can be reformed, the prevailing cabinet format, or the power of prime minis ters and heads of state in the government formation (Amorim Neto and Strøm 2006; Schleiter and Morgan-Jones 2009; Strøm et al. 2003). To alleviate these problems, we outline a cross-national design below that allows us to go beyond single countries while remaining attentive to crucial country-specific peculiarities with regard to data collection. Before, the next section develops theoretical expectations on the conditions under which reforms of portfolio design should occur.

\section{Explaining changes in portfolio design}

The core theoretical claim of this article holds that portfolio design reforms are driven by a 'political logic', i.e. parties and politicians change the design of government portfolios according to their political preferences. ${ }^{2}$ One way to test this core expectation is studying the timing of reforms. ${ }^{3}$ If portfolio design is changed for political reasons, reforms should cluster temporally after events that change the preference constellation among the relevant political actors. Changes in the cabinet are

2 Public administration research attributes changes in portfolio design to the workability of the 'machinery of government'. While empirical research on individual reforms finds examples where these concerns play a role (Busse 2006; Davis et al. 1999; Derlien 1996; Heppell 2011; Kavanagh and Richards 2001; Pollitt 1984; White and Dunleavy 2010), even proponents concede that efficiency concerns are only one of many reasons for reallocating jurisdictions (Davis et al. 1999; Derlien 1996; Pollitt 1984).

${ }^{3}$ Timing is certainly not the only way to identify a political logic in portfolio design reforms. More targeted analyses analyze the content and beneficiaries of reforms based on specific assumptions about the goals of political actors such as increasing their expected office and policy payoffs or controlling coalition partners by creating overlapping jurisdictions between ministries. We discuss these perspectives for future research in more detail in the concluding section. 
the most important events in this respect. However, cabinets can change in various ways. Distinguishing between different types of changes, we can go beyond the simple expectation that the preference constellation in the cabinet matters for portfolio design reforms and identify which changes are decisive.

For this purpose, our analysis focuses on four events: A change in party composition, a change in the person of the prime minister, a change in cabinet ideology, and a change in the partisan fragmentation of the cabinet. The first two affect cabinets on a very fundamental level by exchanging at least some of the relevant actors. Thus, they are most likely to trigger reforms. In contrast, changes in cabinet ideology and the partisan fragmentation of the cabinet provide a gradual measure of the magnitude of changes in the cabinet. At the same time, these two measures are largely contingent on changes in the cabinet's party composition, i.e. they are usually stable in the absence of changes in cabinet composition. ${ }^{4}$ Thus, these variables allow us to test whether the magnitude of changes in the cabinet yields any additional effect on portfolio design reform beyond the fact that the cabinet changes at all. In the empirical analysis, we address the dependence between the different change measures by estimating models for single events as well as a joint model.

First, changes in the party composition of the cabinet should make portfolio design reforms more likely. New cabinet parties may want to structure government portfolios differently than their predecessors to reflect changes in the government's policy priorities, for example, by creating independent departments for policy areas that are

\footnotetext{
${ }^{4}$ In theory, the ideological position of the cabinet can also change without any alteration in cabinet parties and their sizes only due to changes in parties' ideological positions. In our empirical analysis, however, this is rarely the case because we rely on expert survey measures of ideology that are only measured at a few time points.
} 
high on the government's issue agenda (Mortensen and Green-Pedersen 2015). Thus, we expect:

Hypothesis 1: Changes in portfolio design become more likely when the party composition of the government changes.

Second, a change to a new prime minister constitutes a key event for any cabinet because the preferences and personality of prime ministers have strong substantive and symbolic impact on their cabinets. ${ }^{5}$ For example, prime ministers often differ in their leadership style and the way they solve conflicts within the cabinet (Helms 2005; Poguntke and Webb 2005; Timmermans 2003). Therefore, a new prime minister could aim to change portfolio design as an aspect of coalition governance to his or her liking. This argument is particularly strong in countries like Germany, where portfolio design is the prerogative of the head of government. Thus, we hypothesize:

Hypothesis 2: Changes in portfolio design become more likely when the Prime minister changes.

Hypotheses 1 and 2 focus on changes in the cabinet's composition. In the following, we analyse two factors that go beyond binary reform measures and capture the magnitude of change that takes place. For one, changes in portfolio design could depend on the ideological differences between the current cabinet and its predecessor (Dahlström and Holmgren 2017). Ideological shifts between cabinets are often associated with changes in issue positions and priorities of the cabinet parties. Parties might thus feel the need to change the design of government portfolios in ways that reflect these new priorities. For example, the new Danish centre-right coalition

\footnotetext{
${ }^{5}$ In fact, most scholars treat changes in the prime ministership as an event that terminates a government (e.g. Müller and Strøm 2000).
} 
government in 2001 established an independent ministry for 'refugees, immigrants and integration' and stripped down the competencies of the 'environment and energy' department (e.g. moving 'energy' to the economics department). Thus, we hypothesize:

Hypothesis 3: Changes in portfolio design become more likely when the ideological position of the cabinet changes.

Moreover, changes in the relative size of parties within the cabinet could have an additional effect on portfolio design. Ample research shows that party size is a crucial predictor of the distribution of office and policy payoffs within coalitions (e.g. Bäck et al. 2011; Warwick and Druckman 2006). Beyond a strong orientation towards proportionality, several studies show that small parties are slightly overpaid with regard to the number of portfolios (Browne and Franklin 1973; Warwick and Druckman 2006). One way to allocate more office to small parties is to adapt portfolio design, e.g. by splitting ministries or moving policy jurisdictions to ministries controlled by small parties (Sieberer 2015). Changes in the relative sizes of cabinet parties can be measured via the partisan fragmentation within the cabinet leading to the following hypothesis:

Hypothesis 4: Changes in portfolio design become more likely when the fragmentation in the cabinet changes.

\section{Studying portfolio design comparatively}

In this section, we outline our approach to studying portfolio design comparatively across nine Western European democracies. While our conceptual definition of portfolio design and its reform is quite straightforward, measuring it empirically is a rather complex task that requires in-depth field knowledge to gather and correctly code 
the relevant information. For one, the power to determine portfolio design is granted to different actors, i.e. the head of state in some countries, the head of government in others, and the legislature via law-making in yet others. Second, in many instances the documents outlining portfolio design are not readily available but have to be identified via archival work, especially for earlier periods. Third, reforms include both substantive changes and minuscule administrative or purely technical changes (such as correcting typos) that are not always easy to distinguish. Finally, some ministerial jurisdictions are country-specific and their relevance is hard to judge without in-depth knowledge of the respective political system.

To deal with these challenges, we collected data in a decentralized way as a team of country experts based on joint coding instructions. This strategy achieves an optimal balance between country-specific expertise and conceptual coherence. We analyse portfolio design reforms in nine West European countries over up to 45 years (from 1 January 1970 to 31 December 2015): Austria, Denmark, France, Germany, Italy, the Netherlands, Norway, Spain, and Sweden (see Table 1). This set of countries provides substantial variation in institutional setup and party system characteristics, e.g. regarding the power and role of prime ministers (Strøm et al. 2003), formal powers of heads of state (Amorim Neto and Strøm 2006), the government formation process (Laver and Schofield 1990, 210), the types of governments that are formed (Müller and Strøm 2000), and the format of the party system (Mair 2002).

Based on our definition of portfolio design, we code changes in portfolio design as instances in which the distribution of competencies among departments (ministries) changes or the distribution of competencies among office holders (ministers and junior ministers) is modified. Thus, mere cabinet reshuffles without an alternation in policy responsibilities are not analysed. By contrast, changes in the number of departments 
and/or office holders do constitute a change in portfolio design because new or discarded offices and/or office holders gain or lose competencies, respectively. In addition, moving officeholders (most notably junior ministers) with fixed competencies between departments also counts as a change in portfolio design. As Table 1 indicates, the formal rules in which portfolio design is codified, and thus the data sources for our coding, vary across countries. The empirical analysis below controls for these differences.

Table 1: Countries, sources for changes in portfolio design, and time span

\begin{tabular}{lll}
\hline Country & Formal rules for portfolio design & Time span \\
\hline Austria & Law & $1970-2015$ \\
Denmark & Royal decree & $1971-2015$ \\
France & Presidential decree & $1970-2015$ \\
Germany & Organizational decree & $1970-2015$ \\
Italy & Law & $1970-2015$ \\
Netherlands & Royal decree & $1995-2015$ \\
Norway & Royal decree & $1970-2015$ \\
Spain & Royal decree & $1977-2015$ \\
Sweden & Royal decree & $1982-2015$ \\
\hline
\end{tabular}

Note: In Spain, data collection starts with transition to democracy. In Sweden and the Netherlands, the relevant documents to code portfolio design are not readily accessible before 1982 and 1995, respectively.

Based on these data sources, the country experts identified all changes in portfolio design during the period of investigation and provided a short description of the reform (Which departments were involved? Which competencies were affected?). In a second step, we excluded purely technical reforms and instances with no (or very minor) changes in policy jurisdictions. Moreover, consecutive changes within a few days that were clearly part of a single process are treated as one reform and dated with the 
earliest available date to capture the starting point of the reform process. ${ }^{6}$ In total, we identified 339 changes in portfolio design in our sample. ${ }^{7}$ In the supplemental material (Appendix A), we describe three randomly selected reforms from our dataset in greater detail showing that these changes were substantial and had the potential to affect policy processes and outcomes.

\section{Empirical results}

This section presents empirical results on the frequency and timing of portfolio design reforms. It shows that the 'fixed structure' assumption of an exogenously given design of ministerial portfolios is often violated. ${ }^{8}$ Furthermore, the timing of reforms suggests that political motives play a major role. More specifically, we find that changes in portfolio design are much more likely after changes in the party composition of the cabinet (H1) and the identity of the prime minister (H2), whereas changes in the cabinet's ideological position (H3) and its fragmentation (H4) have only weak additional effects.

\section{The frequency of changes in portfolio design}

Table 2 shows the average time (in days) that a given portfolio design is in place across countries and over time. The data indicate that the distribution of competencies between departments or office holders changes frequently: on average, the portfolio design is changed about once a year (mean duration: 387 days). Yet, the frequency

\footnotetext{
${ }^{6}$ For example, single reforms often produce more than one document in France because two distinct types of decrees regulate the composition of the cabinet and the attribution of policy competencies and administrative capacities to the newly appointed ministers.

${ }^{7} \mathrm{~A}$ list of all reforms with short descriptions is available at: https://dataverse.harvard.edu/dataverse/BJPolS.

8 This article focuses on the frequency of portfolio design changes. For an impression of the magnitude and substantive importance of the reforms, we refer readers to the supplemental material (Appendix A).
} 
varies substantially across countries. Reforms occur most often in France, where a given design changes (on average) about twice a year (mean duration: 173 days), and the Netherlands (mean duration: 211 days). By contrast, changes are most rare in Austria, where portfolio designs are (on average) in place for more than two years (mean duration: 851 days).

Table 2: Mean duration (in days) between changes in portfolio design

\begin{tabular}{lccccc}
\hline Country & $1970 s$ & $1980 s$ & $1990 s$ & $2000 s$ & Mean \\
\hline Austria & 1152.3 & 901.0 & 718.0 & 803.3 & 851.4 \\
Denmark & 419.3 & 841.0 & 733.3 & 762.2 & 670.5 \\
France & 168.9 & 143.6 & 176.0 & 198.7 & 173.2 \\
Germany & 461.0 & 1071.0 & 411.1 & 691.3 & 610.3 \\
Italy & 310.6 & 303.3 & 271.8 & 304.4 & 297.0 \\
Netherlands & & & 262.2 & 200.8 & 211.0 \\
Norway & 809.3 & 574.0 & 639.5 & 443.5 & 543.3 \\
Spain & 640.0 & 483.6 & 713.8 & 951.3 & 699.3 \\
Sweden & & 338.9 & 315.1 & 413.0 & 364.6 \\
\hline Mean & 377.1 & 400.2 & 363.0 & 396.2 & 386.5 \\
\hline
\end{tabular}

Note: Reforms from 2011 to 2015 are grouped into the '2000s' category.

This cross-country variation does not seem to be linked to the second-order rules of how portfolio design is changed. In Austria and Italy, changes in the competencies between different departments are regulated by law, which requires approval by a parliamentary majority and thus arguably involves more veto players than in countries where reforms are possible via decrees. ${ }^{9}$ However, the two countries differ markedly with regard to reform frequency. While portfolio design is in fact rather stable in Austria, it changes frequently in Italy. Moreover, there is substantial variation across

\footnotetext{
${ }^{9}$ We write 'primarily' as not all changes in portfolio design are regulated by law or decrees. For example, in Austria, ministers can change the jurisdictions of junior ministers within their department without the consent of other political actors.
} 
countries that use some sort of decree to change the competencies between different departments and office holders.

There is also no clear time trend in our data beyond some country-specific patterns. Changes in portfolio design become more likely over time in Austria and, to a lesser extent, in Norway whereas reforms in Denmark were more frequent in the 1970s than today. Yet, by and large we see no clear temporal trends that are worth noting.

\section{Explaining the timing of changes in portfolio design}

This section employs event history analysis to test our hypotheses on the timing of reforms. We use Cox proportional hazards models to estimates the 'hazard rate', i.e. 'the instantaneous probability that an event occurs given that the event has not yet occurred' (Box-Steffensmeier and Jones 1997, 1427). In our context, the hazard rate describes the probability that the portfolio design currently in place is reformed at a specific point in time depending on various covariates, most notably the occurrence of the four events identified above. As these events can occur at different times during a given portfolio design, they are modelled as time-variant covariates. At the beginning of each observation (i.e. day 1 of a new portfolio design), the variables for all four events have the value ' 0 '. After an event (e.g. a change of the prime minister) occurred, the respective variable takes the value ' 1 ' (for dichotomous variables) or the value of the magnitude of the change (for continuous variables). To test $\mathrm{H} 1$ and $\mathrm{H} 2$, we use two dichotomous variables that indicate changes in the cabinet's party composition (H1) and the prime ministership (H2). To measure changes in the cabinet's policy position (H3), we calculate the position of each cabinet as the seat share-weighted average of cabinet parties' left-right positions as measured by expert surveys (on a 0-10 scale) and then use the absolute difference between the positions of the current cabinet and its predecessor. For measuring the change in fragmentation within the cabinet (H4), 
we use the absolute difference in the effective number of cabinet parties from the previous to the current cabinet (Laakso and Taagepera 1979).The data on these four variables are taken from the ParlGov database (Döring and Manow 2018).

Beyond these key variables used to test our hypotheses, we also include a time-varying covariate that captures the occurrence of general elections. Elections are key turning points for parties to change their issue positions and issue emphasis (Walgrave and Nuytemans 2009), which could also trigger portfolio design reforms. Election dates for legislative and (in France) presidential elections are taken from the Parline database of the Inter-parliamentary Union (https://www.ipu.org) and various national data archives.

Furthermore, we include control variables that identify caretaker cabinets, coalition cabinets, the formal rules for changing portfolio design, changes in economic conditions, and the time period. Caretaker cabinets usually expect only a short tenure in office and could thus have a lower probability of portfolio design changes. By contrast, reforms should be more frequent under coalitions compared to single-party cabinets because the political logic outlined above suggests that parties use portfolio design to divide policy jurisdictions among the coalition partners. Data for both variables are taken from the ParlGov database. Third, changes in portfolio design could be less likely in countries where such reforms require laws (1) rather than decrees (0) because the need for parliamentary approval arguably involves more veto players. Fourth, we account for annual changes in the unemployment rate using data from the Quality of Government dataset (Teorell et al. 2018). Increasing unemployment may point to poor performance of the current institutional setup and could trigger changes in portfolio design. Finally, we include dummy variables for 
decades to test whether portfolio design reforms have become more frequent over time. ${ }^{10}$ Overall, we have data on 327 portfolio designs. ${ }^{11}$

We test our hypotheses with Cox proportional hazard models. As the four events we are interested in are empirically related, we first estimate separate models for each event before turning to a full model with all four. Statistical tests show that the crucial model assumption of proportional hazards is violated in all model specifications (Grambsch and Therneau 1994) and Harrell's rho tests (Box-Steffensmeier and Jones 2004, 135) are used to identify the variables causing this violation. In each specification, the relevant variables are interacted with (the log of) time (BoxSteffensmeier and Jones 2004, 136-37). Additional robustness tests that include country fixed effects to address any remaining country-specific variation yield equivalent results (see the supplementary material; Appendix B).

Table 3 shows that regression results for the five model specifications. Models 1 to 4 test our four hypotheses separately whereas model 5 includes all variables of interest. Positive coefficients indicate an increase in the hazard rate, and thus a higher likelihood of a portfolio design change.

\footnotetext{
10 The years from 2011 to 2015 are subsumed in the 2000s dummy variable.

11 Observations at the end of the observation period (31 December 2015) are treated as right-censored.
} 
Table 3: Analysing the timing of changes in portfolio design

\begin{tabular}{|c|c|c|c|c|c|}
\hline & M1 & M2 & M3 & M4 & M5 \\
\hline$\Delta$ Partisan composition of cabinet & $\begin{array}{c}1.634^{* * *} \\
(0.158)\end{array}$ & & & & $\begin{array}{c}1.889^{* * *} \\
(0.253)\end{array}$ \\
\hline$\Delta$ Prime minister & & $\begin{array}{c}3.425^{* * *} \\
(0.848)\end{array}$ & & & $\begin{array}{c}4.125^{* * *} \\
(1.041)\end{array}$ \\
\hline$\Delta$ Prime minister $X \ln ($ time $)$ & & $\begin{array}{c}-0.376^{*} \\
(0.146)\end{array}$ & & & $\begin{array}{c}-0.622^{* * *} \\
(0.175)\end{array}$ \\
\hline $\mid \Delta$ Cabinet policy position $\mid$ & & & $\begin{array}{c}0.294^{* * *} \\
(0.057)\end{array}$ & & $\begin{array}{c}-1.477^{* *} \\
(0.453)\end{array}$ \\
\hline $\mid \Delta$ Cabinet policy position $\mid X \ln ($ time $)$ & & & & & $\begin{array}{l}0.230^{* *} \\
(0.076)\end{array}$ \\
\hline $\mid \Delta$ Effective no of government parties $\mid$ & & & & $\begin{array}{c}0.583^{* * *} \\
(0.142)\end{array}$ & $\begin{array}{c}-0.609^{* *} \\
(0.207)\end{array}$ \\
\hline General election & $\begin{array}{c}4.654^{* * *} \\
(0.887)\end{array}$ & $\begin{array}{c}3.955^{* * *} \\
(0.950)\end{array}$ & $\begin{array}{c}4.459^{* * *} \\
(0.869)\end{array}$ & $\begin{array}{c}4.639^{* * *} \\
(0.851)\end{array}$ & $\begin{array}{c}4.748^{* * *} \\
(0.966)\end{array}$ \\
\hline General election X $\ln$ (time) & $\begin{array}{c}-0.630^{* * *} \\
(0.157)\end{array}$ & $\begin{array}{c}-0.470^{* *} \\
(0.167)\end{array}$ & $\begin{array}{c}-0.540^{* * *} \\
(0.153)\end{array}$ & $\begin{array}{c}-0.556^{* * *} \\
(0.150)\end{array}$ & $\begin{array}{c}-0.618^{* * * *} \\
(0.171)\end{array}$ \\
\hline Caretaker government & $\begin{array}{c}0.309 \\
(0.293)\end{array}$ & $\begin{array}{c}0.326 \\
(0.297)\end{array}$ & $\begin{array}{c}0.232 \\
(0.302)\end{array}$ & $\begin{array}{l}0.0517 \\
(0.298)\end{array}$ & $\begin{array}{c}0.441 \\
(0.306)\end{array}$ \\
\hline Coalition government & $\begin{array}{c}0.309^{*} \\
(0.136)\end{array}$ & $\begin{array}{l}0.404^{* *} \\
(0.136)\end{array}$ & $\begin{array}{l}0.446^{* *} \\
(0.137)\end{array}$ & $\begin{array}{l}0.411^{* *} \\
(0.137)\end{array}$ & $\begin{array}{l}0.290^{*} \\
(0.140)\end{array}$ \\
\hline Formal rules: law & $\begin{array}{l}-1.374^{+} \\
(0.723)\end{array}$ & $\begin{array}{l}-1.657^{*} \\
(0.750)\end{array}$ & $\begin{array}{c}-0.0943 \\
(0.142)\end{array}$ & $\begin{array}{c}-0.0661 \\
(0.142)\end{array}$ & $\begin{array}{c}-2.922^{* *} \\
(0.893)\end{array}$ \\
\hline Formal rules: law $\mathrm{X} \ln$ (time) & $\begin{array}{c}0.207 \\
(0.130)\end{array}$ & $\begin{array}{c}0.253^{+} \\
(0.132)\end{array}$ & & & $\begin{array}{l}0.438^{* *} \\
(0.154)\end{array}$ \\
\hline Time (reference: 1970s) & & & & & \\
\hline $1980 \mathrm{~s}$ & $\begin{array}{c}0.0720 \\
(0.201)\end{array}$ & $\begin{array}{r}-0.0312 \\
(0.198)\end{array}$ & $\begin{array}{c}-0.142 \\
(0.197)\end{array}$ & $\begin{array}{c}-0.0713 \\
(0.199)\end{array}$ & $\begin{array}{l}0.0437 \\
(0.204)\end{array}$ \\
\hline $1990 \mathrm{~s}$ & $\begin{array}{c}-0.0601 \\
(0.196)\end{array}$ & $\begin{array}{l}-0.134 \\
(0.197)\end{array}$ & $\begin{array}{l}-0.234 \\
(0.195)\end{array}$ & $\begin{array}{l}-0.192 \\
(0.195)\end{array}$ & $\begin{array}{r}-0.0462 \\
(0.198)\end{array}$ \\
\hline 2000s & $\begin{array}{l}-0.133 \\
(0.185)\end{array}$ & $\begin{array}{l}-0.157 \\
(0.187)\end{array}$ & $\begin{array}{l}-0.284 \\
(0.189)\end{array}$ & $\begin{array}{l}-0.126 \\
(0.190)\end{array}$ & $\begin{array}{l}-0.195 \\
(0.191)\end{array}$ \\
\hline Change in unemployment rate (in \%) & $\begin{array}{l}0.160^{* *} \\
(0.050)\end{array}$ & $\begin{array}{l}0.161^{* *} \\
(0.050)\end{array}$ & $\begin{array}{l}0.146^{* *} \\
(0.052)\end{array}$ & $\begin{array}{l}0.163^{* *} \\
(0.050)\end{array}$ & $\begin{array}{c}0.175^{* * *} \\
(0.050)\end{array}$ \\
\hline Observations (Portfolio design regime) & 327 & 327 & 327 & 327 & 327 \\
\hline Failures (events of interest) & 318 & 318 & 318 & 318 & 318 \\
\hline Time at risk (in days) & 124,417 & 124,417 & 124,417 & 124,417 & 124,417 \\
\hline Log Likelihood & -1406.4 & -1421.3 & -1443.3 & -1447.4 & -1391.4 \\
\hline
\end{tabular}

Note: Standard errors in parentheses.

${ }^{+} p<0.1,{ }^{*} p<0.05,{ }^{* *} p<0.01,{ }^{* * *} p<0.001$

Models 1 to 4 support all four hypotheses when tested in isolation - all events have a statistically significant positive effect on changes in portfolio design. Yet, hypotheses on the magnitude of change ( $\mathrm{H} 3$ \& $\mathrm{H} 4$ ) are largely contingent on changes in the cabinet's party composition (H1). The full model 5 accounts for this interdependence 
by including all four events in a joint model. The results indicate that two event types are dominant: Changes in party composition (H1) and changes in the person of the prime minister (H2) both have statistically significant and strong positive effects. The negative interaction term with time indicates that the positive effect of prime minister change on the hazard rate diminishes over time, i.e. new prime ministers primarily implement portfolio design reforms early in their tenure. In contrast, we find little evidence for additional effects of changes in the cabinet's ideological position (H3) or in its fragmentation (H4). Against our hypotheses, the coefficients of both variables are negative and statistically significant albeit, as we show below, substantively weak. To interpret these effects in a more meaningful way, we simulate and plot survival functions based on results of the full model for different analytically meaningful scenarios (Ruhe 2016). ${ }^{12}$ Putting the remaining covariates at their means (continuo us variables) and mode (categorical variables) ${ }^{13}$, the graphs in Figure 1 show the probability that a given portfolio design remains in place ('survives') over time depending on the values of our key covariates. The dashed lines indicate the probability of portfolio design stability in the aftermath of the four simulated events. The solid lines indicate survival functions if the respective event had not occurred. ${ }^{14}$

\footnotetext{
12 The plots of the effects based on Models 1 to 4 are shown in the supplementary material (Appendix C).

${ }^{13}$ Specifically, we model effects for a non-caretaker coalition government in the 2000s in a country where portfolio design is changed by decrees (rather than laws), with a slight increase in unemployment ( +0.06 percentage points), and where no other events have taken place. Changes in the cabinet's policy position and fragmentation, however, are contingent on changes in the cabinet's party composition. For these covariates, we assume that the party composition of the cabinet has changed.

${ }^{14}$ For changes in continuous variables, we plot survival functions for a simulated change in the respective variable for 'no change' (zero; roughly the mean) and an increase by one standard deviation.
} 
Figure 1: Predicted stability of portfolio designs
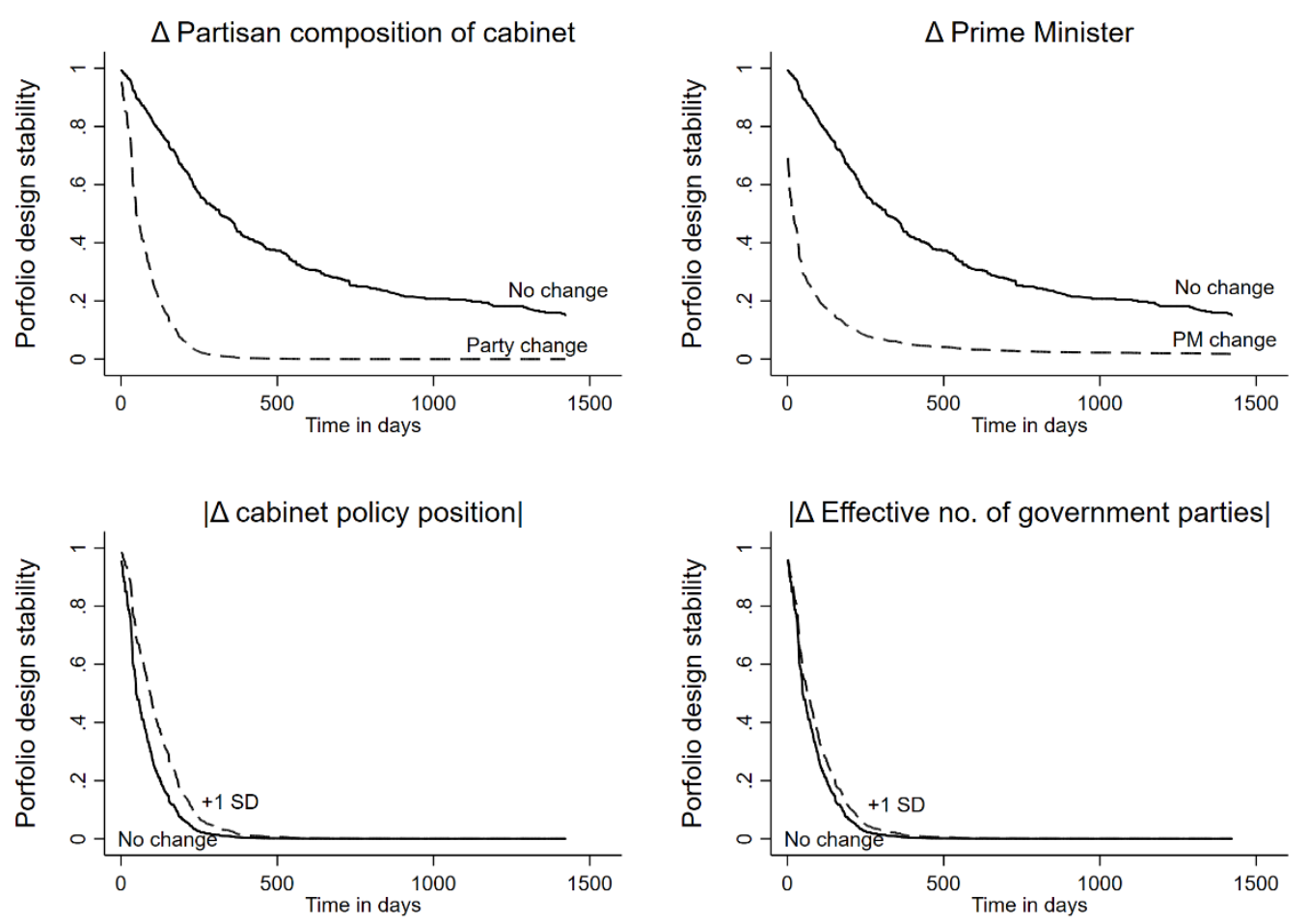

Note: All estimates are based on the Model 5 in Table 3, while the remaining covariates are held constant at their mean or mode, respectively. For the (changes in) continuous variables, curves show the stability for "no change" (zero; roughly the mean) and an increase by one standard deviation. Plots based on the scurve_tvc command by Ruhe (2016).

Figure 1 shows that a reform of portfolio design is much more likely after the party composition of the government has changed (H1; upper left panel in Figure 1). According to the simulation, only about 1 percent of the portfolio designs are still in place one year after a change in the party composition, while without such a change about 46 percent of portfolio designs remain unchanged. A similar pattern emerges for $\mathrm{H} 2$ in the upper right panel of Figure 1. When a new prime minister enters office, the chances that a given portfolio design remains in place decrease dramatically. One year after the event, only about 6 percent of the portfolio designs are still unchanged (compared to 46 percent without a change in the identity of the prime minister). 
According to the model, both variables have very strong effects - it is almost certain that the portfolio deign is reformed within one year after changes in the cabinet's party composition or the prime ministership. However, this result is not all that surprising in light of previous research. Verzichelli (2008) finds that only about one third of all cabinets have the same number of ministers as their predecessors. This measure underestimates changes in policy responsibilities because it only captures net changes (e.g. ignores reforms that create and abolish the same number of ministries) and neglects the transfer of policy jurisdictions between ministries. It is therefore not too surprising to find even more frequent changes using our more fine-grained data.

Against our hypotheses, changes in the cabinet's policy position (H3; lower left panel) and fragmentation (H4, lower right panel) decrease the chances of portfolio design reform when controlling for partisan and prime ministerial change. However, both effects are substantially weak. Changing the cabinet's policy position by one standard deviation ( 0.8 points on a $0-10$ scale) decreases the predicted probability of a reform having occurred after one year by roughly 1 percentage point (from 1 to 2 percent). The effect of changes in the cabinet's fragmentation has roughly the same magnitude. Thus, the overall assessment of Hypotheses 3 and 4 is ambivalent. While both variables have the expected unconditional effects in Models 3 and 4, the full model suggests that these findings are due to the simultaneous occurrence of more fundamental changes such as a new prime minister and a novel partisan composition of the cabinet. These findings indicate that binary measures of fundamental changes are sufficient for explaining reforms in portfolio design whereas gradual measures of the magnitude of changes in the cabinet have no additional effects.

Turning to the control variables, the probability of portfolio design reforms is substantially higher after general elections and for coalition governments. Both 
findings are consistent with a political logic in which elections are decisive events and the distribution of benefits among multiple cabinet parties is a major driver of reforms. The formal rules to change portfolio design (decrees vs. laws) also affect reform frequency: portfolio designs that can only be changed by laws are somewhat more stable than those that can be altered by decrees. The control variable on caretaker status and the decade dummies do not have statistically significant effects. Finally, there is evidence that economic performance affects portfolio design change: the probability of reform increases with increases in the unemployment rate, which can be interpreted as an institutional reaction to performance deficits.

\section{Conclusion}

As the first systematic comparative study of changes in the design of government portfolios in Western European democracies, this article provides two core insights. First, reforms of portfolio design are frequent (339 cases in nine countries over a period of 45 years). This finding casts serious doubt on the standard assumption of coalition researchers that 'the administrative structure of the state changes only very occasionally in the real world' (Laver and Shepsle 1996, 271). Second, these reforms occur after political events, most notably changes in the government's composition in terms of parties and the identity of the prime minister. These findings suggest that changes in portfolio design follow a political logic that is driven by preference alterations among the relevant political actors.

Our findings have important implications for the general literature on institutional design and for coalition research. For one, the patterns of change are consistent with previous research on purposive institutional design showing that reforms of electoral systems, parliamentary organization, and political regime types can be explained with reference to goals and strategies of political actors. While the timing of reforms 
suggests a political logic for portfolio design as well, timing data cannot provide direct evidence for this argument because it does not capture which actors benefit from these reforms.

In future work we seek to explore this question in greater detail. For example, do parties use changes in portfolio design to increase their payoffs in the portfolio allocation process, either in quantitative terms (e.g. Sieberer 2015; Warwick and Druckman 2006) or qualitatively by allocating responsibilities in accordance with parties' substantive priorities (e.g Bäck et al. 2011)? And do government parties deliberately allocate policy jurisdictions to different departments to keep tabs on their coalition partners on highly divisive issues as research on coalition governance suggests (e.g. Carroll and Cox 2012; Martin and Vanberg 2011; Strøm et al. 2008; Thies 2001)? These questions point to more specific motivations of why cabinet parties seek particular changes in portfolio design. More targeted theoretical models based on such motivations yield hypotheses on the conditions under which specific changes should occur and on the beneficiaries of such reforms. Obviously, there is much more to be done to understand why and how political actors use portfolio design to achieve various political goals - and the findings of this article indicate that such analyses based on a political logic of portfolio design merit attention in future research.

Second, the frequency of reforms cast serious doubt on the validity of assuming that government portfolios are exogenous to the government formation process as the vast majority of studies on the allocation of government portfolios does (e.g. Bäck et al. 2011; Carroll and Cox 2007; Ecker et al. 2015; Falcó-Gimeno and Indridason 2013; Laver 1998; Laver and Schofield 1990; Verzichelli 2008; Warwick and Druckman 2006). Our findings suggest that the design of portfolios is not exogenous but should be conceptualized as an important outcome of the government formation process. 
Thus, they highlight the need for an integrative analysis of different decisions taken during coalition formation. These decisions include the partisan composition of the cabinet, its policy program, portfolio allocation, and also portfolio design. Recent work has begun to endogenize some aspects such as the choice of formateur that have previously been taken as exogenous when explaining portfolio allocation (Bassi 2013; Cutler et al. 2016). The findings in this article suggest that the design of cabinet portfolios constitutes another dimension we need to consider in moving towards an integrative analysis of government formation as a multidimensional bargain (Dewan and Hortala-Vallve 2011). 


\section{References}

Amorim Neto O and Strøm K (2006). Breaking the Parliamentary Chain of Delegation. Presidents and Non-partisan Cabinet Members in European Democracies. British Journal of Political Science 36 (4), 619-643.

Andersson S, Bergman T and Ersson S (2014). The European Representative Democracy Data Archive, Release 3. Main Sponsor: Riksbakens Jubileums fond (In2007-0149:1 E) www.erdda.se.

Andeweg RB (2000). Ministers as Double Agents? The Delegation Process between Cabinet and Ministers. European Journal of Political Research 37 (3), 377-395.

André A, Depauw S and Martin S (2016). "Trust is Good, Control is Better". Multiparty Government and Legislative Organization. Political Research Quarterly 69 (1), 108-120.

Bäck H, Debus M and Dumont P (2011). Who Gets What in Coalition Governments? Predictors of Portfolio Allocation in Parliamentary Democracies. European Journal of Political Research 50 (4), 441-478.

Bassi A (2013). A Model of Endogenous Government Formation. American Journal of Political Science 57 (4), 777-793.

Benoit K (2004). Models of Electoral System Change. Electoral Studies 23 (3), 363389.

Benoit K (2007). Electoral Laws as Political Consequences. Explaining the Origins and Change of Electoral Institutions. Annual Review of Political Science 10, 363 390.

Binder SA (1996). The Partisan Basis of Procedural Choice: Allocating Parliamentary Rights in the House, 1789-1990. American Political Science Review 90 (1), 8-20.

Box-Steffensmeier JM and Jones BS (2004). Event History Modeling. A Guide for Social Scientists. Cambridge: Cambridge University Press.

Browne EC and Franklin MN (1973). Aspects of Coalition Payoffs in European Parliamentary Democracies. American Political Science Review 67 (2), 453-469.

Busse V (2006). Organisation der Bundesregierung und Organisationsentscheidungen der Bundeskanzler in ihrer historischen Entwicklung und im Spannungsfeld zwischen Exekutive und Legislative. Der Staat 45 (2), 245-268.

Carroll R and Cox GW (2007). The Logic of Gamson's Law: Pre-election Coalitions and Portfolio Allocations. American Journal of Political Science 51 (2), 300-313.

Carroll R and Cox GW (2012). Shadowing Ministers. Monitoring Partners in Coalition Governments. Comparative Political Studies 45 (2), 220-236.

Cheibub JA (2007). Presidentialism, Parliamentarism, and Democracy. Cambridge: Cambridge University Press.

Cutler J et al. (2016). Cabinet Formation and Portfolio Distribution in European Multiparty Systems. British Journal of Political Science 46 (1), 31-43.

Dahlström C, Peters BG and Pierre J, eds (2011). Steering from the Centre. Strengthening Political Control in Western Democracies. Toronto: University of Toronto Press. 
Davis G et al. (1999). What Drives Maschinery of Government Change? Australia, Canada and the United Kingdom, 1950-1997. Public Administration 77 (1), 7-50.

Derlien H-U (1996). Zur Logik und Politik des Ressortzuschnitts. Verwaltungsarchiv 87 (4), 548-580.

Dewan T and Hortala-Vallve R (2011). The Three As of Government Formation: Appointment, Allocation, and Assignment. American Journal of Political Science 55 (3), 610-627.

Diermeier D and Krehbiel K (2003). Institutionalism as a Methodology. Journal of Theoretical Politics 15 (2), 123-144.

Dion D (1997). Turning the Legislative Thumbscrew. Minority Rights and Procedural Change in Legislative Politics. Ann Arbor, MI: University of Michigan Press.

Döring $\mathbf{H}$ and Manow P (2018). Parliaments and governments database (ParlGov): Information on parties, elections and cabinets in modern democracies. Development version: http://parlgov.org, accessed April 25, 2018.

Druckman JN and Warwick PV (2005). The Missing Piece: Measuring Portfolio Salience in Western European Parliamentary Democracies. European Journal of Political Research 44 (1), 17-42.

Ecker A, Meyer TM and Müller WC (2015). The Distribution of Individual Cabinet Positions in Coalition Governments: A Sequential Approach. European Journal of Political Research 54 (4), 802-818.

Falcó-Gimeno A and Indridason IH (2013). Uncertainty, Complexity, and Gamson's Law: Comparing Coalition Formation in Western Europe. West European Politics 36 (1), 221-247.

Fleischer J (2011). Steering from the German Center: More Policy Coordination and Less Policy Initiatives. In Dahlström C, Peters BG and Pierre J (eds), Steering from the Centre. Strengthening Political Control in Western Democracies. Toronto: University of Toronto Press, pp. 54-79.

Gallagher M and Mitchell P, eds (2005). The Politics of Electoral Systems. Oxford: Oxford University Press.

Grambsch PM and Therneau TM (1994). Proportional Hazards Tests and Diagnostics Based on Weighted Residuals. Biometrika 81 (3), 515-526.

Helms L (2005). Presidents, Prime Ministers and Chancellors: Executive leadership in Western democracies. London: Palgrave MacMillan.

Heppell T (2011). Departmental Restructuring under New Labour. Political Quarterly 82 (3), 425-434.

Huber JD and Shipan CR (2002). Deliberate Discretion? The Institutional Foundation of Bureaucratic Autonomy. Cambridge: Cambridge University Press.

Indridason IH and Bowler S (2014). Determinants of Cabinet Size. European Journal of Political Research 53 (2), 381-403.

Indridason IH and Kam C (2008). Cabinet Reshuffles and Ministerial Drift. British Journal of Political Science 38 (4), 621-656.

Kavanagh D and Richards D (2001). Departmentalism and Joined-up Government:

Back to the Future? Parliamentary Affairs 54 (1), 1-18.

Knill C and Tosun J (2012). Public Policy. A New Introduction. Houndmills: Palgrave MacMillan. 
Laakso M and Taagepera R (1979). 'Effective' Number of Parties. A Measure with Application to Western Europe. Comparative Political Studies 12 (1), 3-27.

Laver M (1998). Models of Government Formation. Annual Review of Political Science 1, 1-25.

Laver M and Schofield N (1990). Multiparty Government: The Politics of Coalition in Europe. Oxford: Oxford University Press.

Laver M and Shepsle KA (1996). Making and Breaking Governments. Cambridge: Cambridge University Press.

—_ eds. (1994). Cabinet Ministers and Parliamentary Government. Cambridge: Cambridge University Press.

Lehnguth G and Vogelgesang K (1988). Die Organisationserlasse der Bundeskanzler seit Bestehen der Bundesrepublik Deutschland im Lichte der politischen Entwicklung. Archiv des Öffentlichen Rechts 113, 531-582.

Mair P (2002). Comparing Party Systems. In LeDuc L, Niemi RG and Norris P (eds), Comparing Democracies 2. New Challenges in the Study of Elections and Voting. London: Sage, pp. 88-107.

Martin LW and Vanberg G (2011). Parliaments and Coalitions. The Role of Legislative Institutions in Multiparty Government. Oxford: Oxford University Press.

Mortensen PB and Green-Pedersen C (2015). Institutional Effects of Changes in Political Attention: Explaining Organizational Changes in the Top Bureaucracy. Journal of Public Administration Research and Theory 25 (1), 165-189.

Müller WC (1994). Models of Government and the Austrian Cabinet. In Laver M and Shepsle KA (eds), Cabinet Ministers and Parliamentary Government. Cambridge: Cambridge University Press, pp. 15-34.

Müller WC (2009). Government Formation. In Landmann T and Robinson N (eds), Handbook of Comparative Politics. London: Sage, pp. 227-245.

Müller WC and Strøm K, eds (2000). Coalition Governments in Western Europe. Oxford: Oxford University Press.

Ostrom E (2005). Understanding Institutional Diversity. Princeton, NJ: Princeton University Press.

Peters, BG, Rhodes RAW and Wright V, eds (2000). Administering the Summit. Administration of the Core Executive in Developed Countries. Basingstoke: Palgrave MacMillan.

Peters BG (2010). The Politics of Bureaucracy. An Introduction to Comparative Public Administration. London: Routledge.

Poguntke, T and Webb PD, eds (2005). The Presidentialization of Politics. A Comparative Study of Modern Democracies. Oxford: Oxford University Press.

Pollitt C (1984). Manipulating the Machine. Changing the Pattern of Ministerial Departments, 1960-83. London: Allen\&Unwin.

Przeworski A (1992). The Games of Transition. In Mainwaring S (ed), Issues in Democratic Consolidation: the New South American Democracies in Comparative Perspective. Notre Dame: University of Notre Dame Press, pp. 105-152.

Raabe J and Linhart E (2014). Disentangling the Value of a Ministry: Party Leaders' Evaluations of German State Ministries. West European Politics 37 (5), 1065-1086. 
Raabe J and Linhart E (2015). Does substance matter? A model of qualitative portfolio allocation and application to German state governments between 1990 and 2010. Party Politics 21 (3), 481-492.

Renwick A (2011). Electoral Reform in Europe since 1945. West European Politics 34 (3), 456-477.

Rhodes RAW and Dunleavy P, eds (1995). Prime Minister, Cabinet and Core Executive. Basingstoke: Macmillan.

Ruhe C (2016). Estimating survival functions after stcox with time-varying coefficients. Stata Journal 16 (4), 867-879.

Saalfeld T and Schamburek D (2014). Labels and Jurisdictions: An Empirical Critique of Standard Models of Portfolio Allocation in Political Science. In Raunio T and Nurmi H (eds), The Serious Game of Politics: Festschrift for Matti Wiberg. Helsinki: Finnish Political Science Association, pp. 193-219.

Sabatier PA and Weible CM (2007). The Advocacy Coalition Framework. Innovations and Clarifications. In Sabatier PA (ed), Theories of the Policy Process. Boulder, CO: Westview Press, pp. 189-220.

Scharpf FW (1997). Games Real Actors Play. Actor-Centered Institutionalism in Policy Research. Boulder, CO: Westview Press.

Schickler E (2000). Institutional Change in the House of Representatives, 1867-1998: A Test of Partisan and Ideological Power Balance Models. American Political Science Review 94 (2), 269-288.

Schleiter P and Morgan-Jones E (2009). Constitutional Power and Competing Risks. Monarchs, Presidents, Prime Ministers, and the Termination of East and West European Cabinets. American Political Science Review 103 (3), 496-512.

Schnapp K-U (2004). Ministerialbürokratien in westlichen Demokratien. Eine vergleichende Analyse. Opladen: Leske+Budrich.

Sieberer U (2015). Die Politik des Ressortzuschnitts zwischen Koalitionsarithmetik und thematischer Profilierung. Eine koalitionspolitische Erklärung für Kompetenzänderungen der Bundesministerien, 1957-2013. Politische Vierteljahresschrift 56 (1), 77-103.

Sieberer U and Müller WC (2015). Explaining Reforms of Parliamentary Minority Rights. A Theoretical Framework with Case Study Application. West European Politics 38 (5), 997-1019.

Smeddinck U and Tils R (2002). Normgenese und Handlungslogiken in der Ministerialverwaltung. Baden-Baden: Nomos.

Strøm K, Müller WC and Bergman T, eds (2003). Delegation and Accountability in Parliamentary Democracies. Oxford: Oxford University Press.

—, eds (2008). Cabinets and Coalition Bargaining. The Democratic Life Cycle in Western Europe. Oxford: Oxford University Press.

Teorell J et al. (2018). The Quality of Government Standard Dataset, version Jan18. University of Gothenburg: The Quality of Government Institute, DOI: 10.18157/QoGStdJan18.

Thies MF (2001). Keeping Tabs on Partners. The Logic of Delegation in Coalition Governments. American Journal of Political Science 45 (3), 580-598. 
Timmemans A (2003). High Politics in the Low Countries. An Empirical Study of Coalition Agreements in Belgium and the Netherlands. Aldershot: Ashgate.

Tsebelis G (1990). Nested Games. Rational Choice in Comparative Politics. Berkeley, CA: University of California Press.

Verzichelli L (2008). Portfolio Allocation. In Strøm K, Müller WC and Bergman T (eds), Cabinets and Coalition Bargaining. The Democratic Life Cycle in Western Europe. Oxford: Oxford University Press, pp. 237-267.

Vowles J (1995). The Politics of Electoral Reform in New Zealand. International Political Science Review 16 (1), 95-115.

Warwick PV and Druckman JN (2006). The Portfolio Allocation Paradox. An Investigation into the Nature of a Very Strong but Puzzling Relationship. European Journal of Political Research 45 (4), 635-665.

White A and Dunleavy P (2010). Making and Breaking Whitehall Departments. A Guide to Machinery of Government Changes. London: Institute for Government, LSE Public Policy Group.

Zubek R (2015). Coalition Government and Committee Power. West European Politics 38 (5), 1020-1041. 
Online Appendix:

The political dynamics of portfolio design in European democracies 


\section{Appendix A: The substantive importance of changes in portfolio design}

The distribution of competencies seems to change quite frequently between departments and office holders. Yet, the frequency in itself tells little about the substantive importance of these changes. To study this aspect in greater detail, we describe three randomly selected reforms from our dataset in more detail: Germany in November 2005, Denmark in December 2001, and France in May 1974.

On 22 November 2005, Chancellor Angela Merkel (CDU) signed an organizational decree (BKOrgErl 2005 ${ }^{15}$ ) to reshape the design of several ministries. After the (early) elections in September that year, the CDU/CSU entered negotiations with the Social Democrats (SPD). Portfolio design was an important aspect of the coalition negotiations and the coalition agreement signed on 11 November contained a clause according to which major changes in the portfolio design during the legislative period would need the agreement of all partners. ${ }^{16}$ Eleven days later, Angela Merkel was elected chancellor and, on her first day in office, signed the organizational decree to change the design of ministerial portfolios.

The decree contains various significant modifications in the design of ministerial portfolios. The most significant change was to split the former 'super ministry' of 'economic affairs and labour' into two departments. The new (or rather recreated) department for 'labour and social affairs' gained jurisdiction (from the former 'super ministry') over labour market policy, unemployment insurance, employment law, and occupational safety. It also gained jurisdiction over social insurance, the social code, and public assistance programmes from the former department of 'health and social security' (henceforth only 'health'). The new (or rather recreated) department of 'economic affairs and technology' got the remaining jurisdictions from the old super ministry and gained additional competencies from the departments of finance and of 'education and development' (e.g. transport and space). Two additional ministries were renamed, and the head of the chancellor's office became a minister without portfolio (responsible for 'special affairs'). Importantly, responsibility for migration, asylum, and integration was moved from the department for 'family affairs, senior citizens, women and youth' to a newly established junior minister in the chancellor's

\footnotetext{
15 https://www.gesetze-im-internet.de/bkorgerl_2005/BJNR319700005.html

16 https://www.cdu.de/artikel/gemeinsam-fuer-deutschland-mit-mut-undmenschlichkeit-koalitionsvertrag-2005
} 
office. In sum, the changes in the organizational decree affected eight of the 16 cabinet members.

The Danish reform in December 2001 shares some similarities with the German case. The Social Democrats had been in government, but lost the general election in November 2001. Anders Fogh Rasmussen's Venstre became the biggest party in parliament and formed a (minority) coalition government with the Conservatives (Det Konservative Folkeparti). The new cabinet entered office on 27 November, and about one month later, the prime minister signed the Danish royal proclamation BEK 1107 on 20 December $2001 .{ }^{17}$ The changes affected the jurisdictions of several ministers. A minister for 'refugees, immigrants and integration' took over competencies from the ministers of the interior (e.g. residence permits), justice (e.g. citizenship), education (e.g. language teaching), finance, cities and housing, and social affairs. The department for 'IT and research' was recast into 'science, technology and development' gaining responsibilities from the department of education (esp. higher education) and business affairs. Two former independent departments (economy and business affairs) were merged and jurisdictions over interior and health were fused in a 'ministry of the interior and health'. The ministry of 'labour' changed its name to 'employment' and gained competencies from the department of social affairs (e.g. active employment policy). The former department for 'Cities and Housing' was abolished and most of its jurisdictions were moved to the department of 'economic and business affairs'. The former ministry for 'environment and energy' lost many of its key jurisdiction which were transferred to the departments of 'economy \& business affairs' (esp. energy), culture (e.g. monument preservation), education (forestry colleges), and foreign affairs (e.g. development aid with relation to the environment). In sum, these changes indicate a shift in the issue agenda of the newly installed centre-right government.

The French reform in May 1974 followed the presidential election in that year that Valéry Giscard d'Estaing won in a close race against François Mitterrand. In an attempt to moderate tensions in the Gaullist camp, he nominated Jacques Chirac as prime minister on 27 May. The day after, the 'decret du 28 mai 1974 portant nomination des membres du government' was published. ${ }^{18}$ The reform contained in

\footnotetext{
17 https://www.retsinformation.dk/Forms/R0710.aspx?id=20966 18

http://www.gouvernement.fr/sites/all/ve/pdf/jo_giscard_gvt_chirac_29mai74_9juin7 4.pdf
} 
the decree affected several ministries. The jurisdiction over 'industry, trade, and handwork' was split into two ministries ('ministry of industry' \& 'ministry of trade and handwork'). The ministries for 'post and telecommunication' and 'cultural affairs and environment' were dissolved and the jurisdictions transferred to state secretaries subordinate to ministers or the prime minister. In turn, new ministries for ‘cooperation', 'reforms', and 'external trade' were created.

In sum, all three reforms are examples of substantively important reforms in portfolio designs: ministries were merged, split, created, or abandoned. Many jurisdictions were moved between departments, and the changes affected several departments and/or office holders. These changes are certainly more than just cosmetics - they signal the designated policy change of governments (e.g. the migration ministry in Denmark) and how policies are framed (e.g. energy as an environmental or an economic issue). 
Table B.1: Analysing the timing of changes in portfolio design

\begin{tabular}{|c|c|c|c|c|c|}
\hline & M1 & M2 & M3 & M4 & M5 \\
\hline$\Delta$ Partisan composition of cabinet & $\begin{array}{c}1.753^{* * *} \\
(0.167)\end{array}$ & & & & $\begin{array}{c}1.588^{* * *} \\
(0.246)\end{array}$ \\
\hline$\Delta$ Prime minister & & $\begin{array}{c}3.821^{* * *} \\
(0.872)\end{array}$ & & & $\begin{array}{c}4.084^{* * *} \\
(1.053)\end{array}$ \\
\hline$\Delta$ Prime minister $X \ln ($ time $)$ & & $\begin{array}{c}-0.409^{* *} \\
(0.151)\end{array}$ & & & $\begin{array}{c}-0.591^{* * *} \\
(0.180)\end{array}$ \\
\hline $\mid \Delta$ Cabinet policy position $\mid$ & & & $\begin{array}{c}0.380^{* * *} \\
(0.061)\end{array}$ & & $\begin{array}{l}-0.959^{*} \\
(0.448)\end{array}$ \\
\hline $\mid \Delta$ Cabinet policy position $\mid X \ln ($ time $)$ & & & & & $\begin{array}{l}0^{0.163}{ }^{*} \\
(0.076)\end{array}$ \\
\hline $\mid \Delta$ Effective no of government parties $\mid$ & & & & $\begin{array}{c}0.788^{* * *} \\
(0.155)\end{array}$ & $\begin{array}{l}-0.446^{*} \\
(0.215)\end{array}$ \\
\hline General election & $\begin{array}{c}3.618^{* * *} \\
(0.886)\end{array}$ & $\begin{array}{c}3.165^{* * *} \\
(0.912)\end{array}$ & $\begin{array}{c}3.459^{* * *} \\
(0.859)\end{array}$ & $\begin{array}{c}3.459^{* * *} \\
(0.855)\end{array}$ & $\begin{array}{c}3.558^{* * *} \\
(0.952)\end{array}$ \\
\hline General election X $\ln$ (time) & $\begin{array}{l}-0.403^{*} \\
(0.159)\end{array}$ & $\begin{array}{c}-0.289^{+} \\
(0.163)\end{array}$ & $\begin{array}{c}-0.326^{*} \\
(0.154)\end{array}$ & $\begin{array}{l}-0.318^{*} \\
(0.153)\end{array}$ & $\begin{array}{c}-0.385^{*} \\
(0.170)\end{array}$ \\
\hline Caretaker government & $\begin{array}{c}-0.189 \\
(0.330)\end{array}$ & $\begin{array}{l}-0.248 \\
(0.335)\end{array}$ & $\begin{array}{c}-0.384 \\
(0.338)\end{array}$ & $\begin{array}{l}-0.515 \\
(0.332)\end{array}$ & $\begin{array}{l}-0.101 \\
(0.338)\end{array}$ \\
\hline Coalition government & $\begin{array}{c}-0.208 \\
(0.169)\end{array}$ & $\begin{array}{l}-0.146 \\
(0.169)\end{array}$ & $\begin{array}{c}-0.0728 \\
(0.169)\end{array}$ & $\begin{array}{l}-0.101 \\
(0.170)\end{array}$ & $\begin{array}{l}-0.206 \\
(0.171)\end{array}$ \\
\hline Formal rules: law & $\begin{array}{l}-1.253 \\
(0.946)\end{array}$ & $\begin{array}{l}-1.643 \\
(1.000)\end{array}$ & $\begin{array}{l}-0.744^{*} \\
(0.332)\end{array}$ & $\begin{array}{l}-0.660^{+} \\
(0.340)\end{array}$ & $\begin{array}{l}-2.687^{*} \\
(1.129)\end{array}$ \\
\hline Formal rules: law $\mathrm{X} \ln$ (time) & $\begin{array}{c}0.0899 \\
(0.145)\end{array}$ & $\begin{array}{c}0.153 \\
(0.152)\end{array}$ & & & $\begin{array}{c}0.305^{+} \\
(0.171)\end{array}$ \\
\hline Time (reference: 1970s) & & & & & \\
\hline $1980 \mathrm{~s}$ & $\begin{array}{c}0.126 \\
(0.203)\end{array}$ & $\begin{array}{l}0.0438 \\
(0.200)\end{array}$ & $\begin{array}{r}-0.0327 \\
(0.199)\end{array}$ & $\begin{array}{l}0.0771 \\
(0.200)\end{array}$ & $\begin{array}{l}0.0902 \\
(0.206)\end{array}$ \\
\hline $1990 \mathrm{~s}$ & $\begin{array}{c}0.0923 \\
(0.200)\end{array}$ & $\begin{array}{l}0.0497 \\
(0.201)\end{array}$ & $\begin{array}{c}-0.0340 \\
(0.201)\end{array}$ & $\begin{array}{l}0.0267 \\
(0.200)\end{array}$ & $\begin{array}{l}0.0712 \\
(0.202)\end{array}$ \\
\hline $2000 s$ & $\begin{array}{l}0.0148 \\
(0.192)\end{array}$ & $\begin{array}{l}0.0939 \\
(0.193)\end{array}$ & $\begin{array}{c}-0.0356 \\
(0.198)\end{array}$ & $\begin{array}{c}0.163 \\
(0.197)\end{array}$ & $\begin{array}{c}-0.0282 \\
(0.198)\end{array}$ \\
\hline Change in unemployment rate (in \%) & $\begin{array}{c}0.202^{* * *} \\
(0.055)\end{array}$ & $\begin{array}{c}0.211^{* * *} \\
(0.055)\end{array}$ & $\begin{array}{l}0.189^{* *} \\
(0.058)\end{array}$ & $\begin{array}{c}0.208^{* * *} \\
(0.055)\end{array}$ & $\begin{array}{c}0.220^{* * *} \\
(0.056)\end{array}$ \\
\hline Country fixed effects & Yes & Yes & Yes & Yes & Yes \\
\hline Observations (Portfolio design regime) & 327 & 327 & 327 & 327 & 327 \\
\hline Failures (events of interest) & 318 & 318 & 318 & 318 & 318 \\
\hline Time at risk (in days) & 124,417 & 124,417 & 124,417 & 124,417 & 124,417 \\
\hline Log Likelihood & -1343.5 & -1354.9 & -1377.3 & -1382.6 & -1332.8 \\
\hline
\end{tabular}

Note: Standard errors in parentheses; Country fixed effects not reported.

${ }^{+} p<0.1,{ }^{*} p<0.05,{ }^{* *} p<0.01,{ }^{* * *} p<0.001$ 
Figure B.1: Predicted stability of portfolio designs
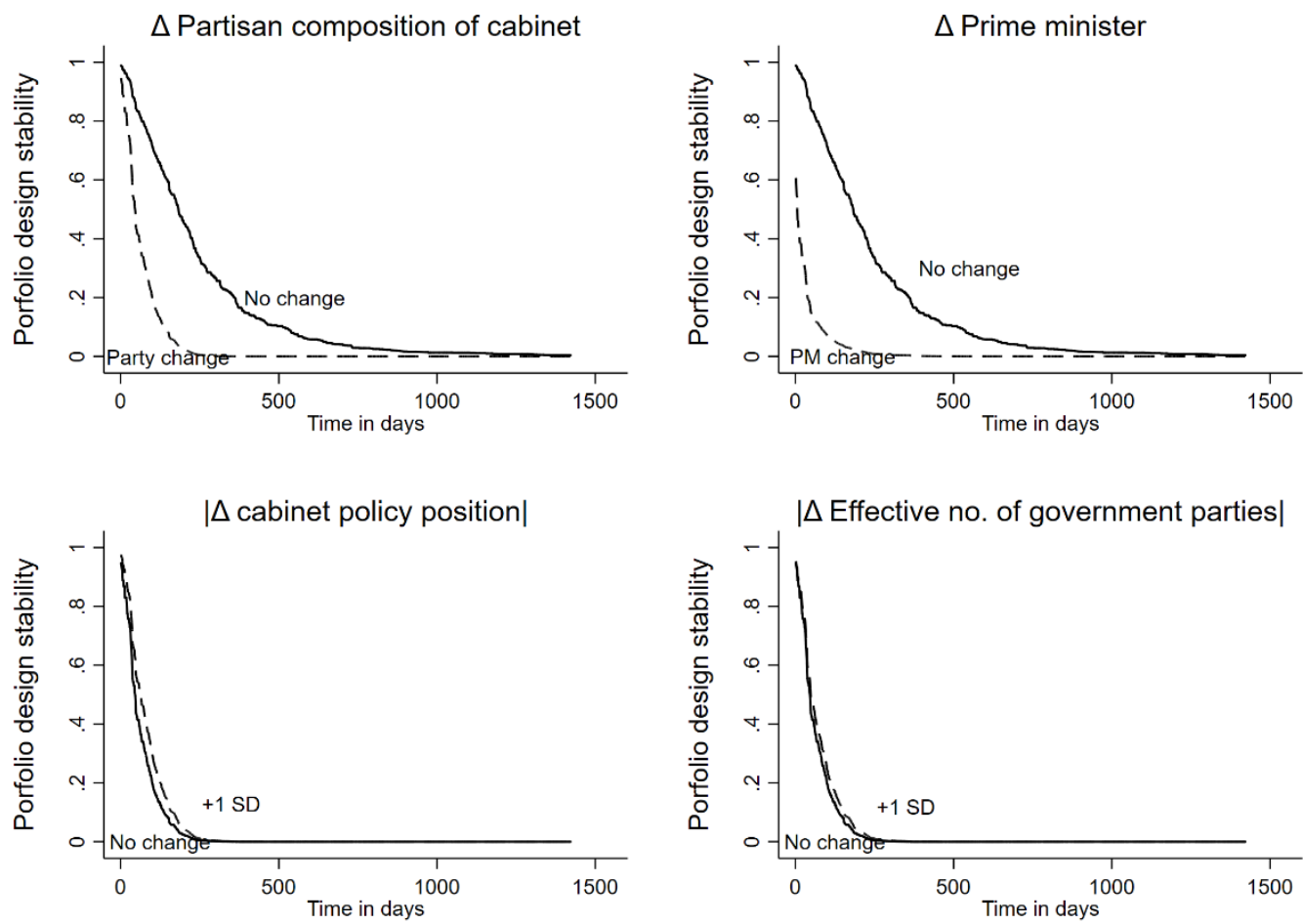

Note: All estimates are based on Model 5 in Table B.1, while the remaining covariates are held constant at their mean or mode, respectively. For the (changes in) continuous variables, curves show the stability for "no change" (zero; roughly the mean) and an increase by one standard deviation. Plots based on the scurve_tvc command by Ruhe (2016). 


\section{Appendix C: Testing Hypotheses 1 to 4 in separate models}

\section{Figure C.1: Predicted stability of portfolio designs}
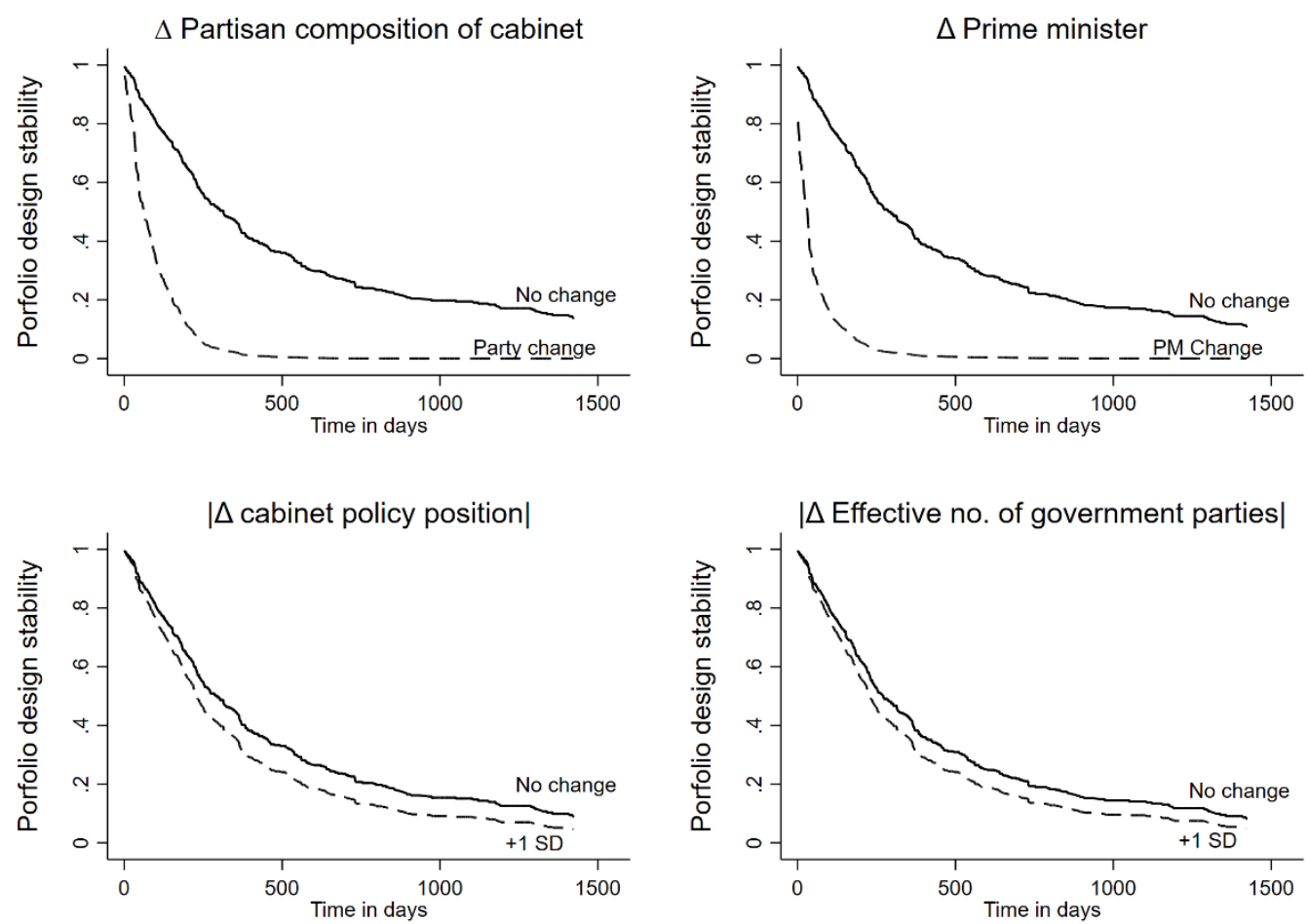

Note: Estimates based on Models 1 to 4 in Table 3 in the article, respectively. The remaining covariates are held constant at their mean or mode, respectively. For the (changes in) continuous variable, curves show the stability for "no change" (zero; roughly the mean) and an increase by one standard deviation. Plots based on the scurve_tvc command by Ruhe (2016). 